\title{
Choosing wisely - choosing tactics
}

Few would deny that quality, not quantity, lies at the heart of healthcare. The Choosing Wisely campaign, initiated by the American Board of Internal Medicine (ABIM) Foundation, the US proponent of professionalism in medicine, aims to cut down on unnecessary testing and ineffective interventions by influencing doctors and informing patients. ${ }^{1}$ From the US/ Canadian Choosing Wisely initiative, via an invitation to the Royal College of Physicians, the campaign has been taken up by the Academy of Medical Royal Colleges (AoMRC). ${ }^{2,3}$ Its aim can be jargonised as culture change, creating a culture in which the clinical value treatments and interventions are discussed by patients and doctors, and inappropriate clinical activity reduced.

In the US and in Canada, an early move was to invite clinicians from the whole spectrum of specialties to publish a list of five 'don'ts' for their sphere of activities; these are available on the web. ${ }^{4}$ It must be said that some of them appear more than self-evident to the UK eye: don't perform electroencephalography for investigation of headache (American Academy of Neurology); ${ }^{5}$ don't initiate chronic dialysis without ensuring a shared decision-making between patients their families and their physicians (American Society of Nephrology); ${ }^{6}$ don't order annual electrocardiograms or any other cardiac screening for low-risk patients without symptoms (American Academy of Family Physicians). ${ }^{7}$ Yet few would disagree with the necessity for the reinforcement of another statement of the obvious - don't perform repetitive CBC and chemistry testing in the face of clinical and lab stability (Society of Hospital Medicine). ${ }^{8}$ The US specialist societies seem to have moved rapidly to provide advice to their members - more than 400 recommendations in total. Interestingly, at least one top 5 recommendation to doctors has not stood the test of time since publication in 2012 - the cardiologists have in the light of new evidence reversed the discouragement of complete cardiac revascularisation. ${ }^{9}$

There seems more meat to the US documents aimed at patients, ${ }^{10}$ although the societies at the time of writing have provided fewer than 90 of these. They are generally highly informative and clear. The leaflet on heartburn (American Gastroenterological Association $)^{11}$ discourages the use of proton pump inhibitors (PPIs), and advocates antacids or
$\mathrm{H}_{2}$-antagonists, with a clear listing of the admittedly low incidence of side effects to PPIs. However, it is notable that in many of the leaflets the basis of funding assumed is 'fee-forservice', and it is striking how this enhances the persuasiveness of the leaflet. The prescription drug price of PPI therapy is pointed out as being approximately $\$ 300$ per month more than antacids. The patient leaflet on the pros and cons of prostate specific antigen testing (American Academy of Family Physicians), ${ }^{12}$ after a clear exposition of the low specificity of the test for cancer, the other potential causes of elevation and the indolent nature of many instances of the tumour, moves to point out how rapidly costs escalate - consultation, ultrasound, other professional fees and biopsy. The Academy of Neurology's patient advice (only two patient leaflets at the time of writing) ${ }^{13}$ covers migraine drugs to avoid, and the pros and cons of carotid artery surgery; the latter flags up uncertain outcomes and highlights both 'the surgery has serious risks' and 'the surgery can cost a lot...may or may not be covered by your insurance'. Money talks, and in that regard, if no other, the lack of direct cost to the patient for most NHS transactions may reduce the impact of the patient educational approach.

There seem to be messages here for how the AoMRC should pursue the Choosing Wisely initiative in the UK. Certainly on first glance, producing and promulgating material for patient education seems likely to be more effective in changing expectations of treatment and therefore practice, than promulgation of what in many cases seem rather self-evident top 5 recommendations for doctors. There is in any case already a compilation of 'do not do' recommendations from NICE guidance. ${ }^{14}$ However, the unspoken leitmotif to all the patient information leaflets is the necessity to spend more time in explanation and discussion with patients.

There are also other strings to the AoMRC's bow. In parallel to the Choosing Wisely initiative, the AoMRC produced a long document last year - Protecting resources, promoting value: a doctor's guide to cutting waste in clinical care. ${ }^{15}$ While not attempting to quantify how much money in total the NHS might save by cutting waste, it points out in substantial detail and with costed examples how relatively simple changes can prevent waste, save money and indeed reduce the carbon footprint of the NHS. The document suggests a concentration

\begin{tabular}{|c|c|}
\hline \multicolumn{2}{|c|}{ Members of the editorial board } \\
\hline $\begin{array}{l}\text { Professor Humphrey Hodgson } \\
\text { Editor }\end{array}$ & $\begin{array}{l}\text { Dr Cordelia Coltart } \\
\text { International edito }\end{array}$ \\
\hline $\begin{array}{l}\text { Dr Paul Grant } \\
\text { Editorial registrar }\end{array}$ & $\begin{array}{l}\text { Cono Ariti } \\
\text { Statistical editor }\end{array}$ \\
\hline
\end{tabular}

Dr Na'eem Ahmed Paul Belcher Dr Rodger Charlton Dr Tahseen Chowdhury Nick Cork

Dr Kate Evans

Professor Brian Hurwitz
Dr Angela King Professor Martin McKee Dr Mehool Patel Dr Roby Rakhit Dr Ian Starke Dr Kevin Stewart Professor Cameron Swift 
of effort on overuse of medication and diagnostic or monitoring tests and procedures, and unplanned admissions. It offers a toolkit for doctors to review and reduce waste in their practice. While the document may lack the international cachet of the Choosing Wisely campaign, the good sense within it should not be eclipsed by the glamour of the latter.

\section{References}

1 American Board of Internal Medicine. Choosing Wisely. Philadelphia, PA: ABIM, 2015. Available online at www.abimfoundation.org/ Initiatives/Choosing-Wisely.aspx [Available 26 May 2015].

2 Academy of Medical Royal Colleges. Choosing wisely programme - a briefing. London: AoMRC, 2015. Available online at www.aomrc.org. uk/doc_download/9830-choosing-wisely.html [Available 26 May 2015].

3 Malhotra A, Maughan D, Ansell J et al. Choosing Wisely in the UK: the Academy of Medical Royal Colleges' initiative to reduce the harms of too much medicine. BMJ 2015:350;h2308.

4 American Board of Internal Medicine. Clinician lists. Philadelphia, PA: ABIM, 2015. Available online at www.choosingwisely.org/clinicianlists/ [Available 26 May 2015].

5 American Academy of Neurology. Five things physicians and patients should question. Philadelphia, PA: ABIM, 2013. Available online at www.choosingwisely.org/societies/american-academy-ofneurology/ [Available 26 May 2015].

6 American Society of Nephrology. Don't initiate chronic dialysis without ensuring a shared decision-making process between patients, their families, and their physicians. Philadelphia, PA: ABIM, 2012. Available online at www.choosingwisely.org/clinician-lists/americansociety-nephrology-chronic-dialysis-without-shared-decisionmaking/ [Available 26 May 2015].

7 American Academy of Family Physicians. Don't order annual electrocardiograms (EKGs) or any other cardiac screening for low-risk patients without symptoms. Philadelphia, PA: ABIM, 2012. Available online at www.choosingwisely.org/clinician-lists/american-academy-familyphysicians-annual-electrocardiograms/ [Available 26 May 2015].
8 Society of Hospital Medicine - Adult Hospital Medicine. Don't perform repetitive $C B C$ and chemistry testing in the face of clinical and lab stability. Philadelphia, PA: ABIM, 2013. Available online at www.choosingwisely.org/clinician-lists/society-hospital-medicineadult-repetitive-cbc-chemistry-testing/ [Available 26 May 2015].

9 American College of Cardiology. Five things physicians and patients should question. Philadelphia, PA: ABIM, 2014. Available online at www.choosingwisely.org/societies/american-college-of-cardiology/ [Available 26 May 2015].

10 American Board of Internal Medicine. Patient-friendly resources. Philadelphia, PA: ABIM, 2015. Available online at www.choosingwisely. org/patient-resources/ [Available 26 May 2015].

11 American Gastroenterological Association. Treating heartburn and GERD - using Nexium, Prilosec, and other PPIs carefully. Philadelphia, PA: ABIM, 2012. Available online at www.choosingwisely.org/ patient-resources/treating-heartburn-and-gerd/ [Available 26 May 2015].

12 American Academy of Family Physicians. PSA blood test for prostate cancer - when men need it - and when they don't. Philadelphia, PA: ABIM, 2014. Available online at www.choosingwisely.org/patientresources/psa-test-for-prostate-cancer/ [Available 26 May 2015].

13 American Academy of Neurology. Carotid artery surgery - when you need it - and when you don't. Philadelphia, PA: ABIM, 2013. Available online at www.choosingwisely.org/patient-resources/ carotid-artery-surgery/ [Available 26 May 2015].

14 National Institute of Health and Care Excellence. 'Do not do' recommendations database. London: NICE, 2015. Available online at www.nice.org.uk/proxy/?sourceurl=http://www.nice.org.uk/ usingguidance/donotdorecommendations/search.jsp [Available 26 May 2015].

15 Academy of Medical Royal Colleges. Protecting resources, promoting value: a doctor's guide to cutting waste in clinical care. London: AoMRC, 2014. Available online at www.aomrc.org.uk/doc download/9793-protecting-resources-promoting-value.html [Available 26 May 2015].

Humphrey Hodgson 